\title{
Oceanic sediment accumulation rates predicted via machine learning algorithm: towards sediment characterization on a global scale
}

\author{
Giancarlo A. Restreppo ${ }^{1,2}$ (D) Warren T. Wood $^{2} \cdot$ Benjamin J. Phrampus ${ }^{2}$
}

Received: 18 February 2020 / Accepted: 24 August 2020 / Published online: 29 August 2020

(C) The Author(s) 2020

\begin{abstract}
Observed vertical sediment accumulation rates $(n=1031)$ were gathered from $\sim 55$ years of peer reviewed literature. Original methods of rate calculation include long-term isotope geochronology $\left({ }^{14} \mathrm{C},{ }^{210} \mathrm{~Pb}\right.$, and $\left.{ }^{137} \mathrm{Cs}\right)$, pollen analysis, horizon markers, and box coring. These observations are used to create a database of global, contemporary vertical sediment accumulation rates. Rates were converted to $\mathrm{cm}_{\text {year }}{ }^{-1}$, paired with the observation's longitude and latitude, and placed into a machine learning-based Global Predictive Seabed Model (GPSM). GPSM finds correlations between the data and established global "predictors" (quantities known or estimable everywhere, e.g., distance from coastline and river mouths). The result, using a k-nearest neighbor (k-NN) algorithm, is a 5-arc-minute global map of predicted benthic vertical sediment accumulation rates. The map generated provides a global reference for vertical sedimentation from coastal to abyssal depths. Areas of highest sedimentation, $\sim 3-8 \mathrm{~cm}_{\text {year }}^{-1}$, are generally river mouth proximal coastal zones draining relatively large areas with high maximum elevations and with wide, shallow continental shelves (e.g., the Gulf of Mexico and the Amazon Delta), with rates falling exponentially towards the deepest parts of the oceans. The exception is Oceania, which displays significant vertical sedimentation over a large area without draining the large drainage basins seen in other regions. Coastal zones with relatively small drainage basins and steep shelves display vertical sedimentation of $\sim 1 \mathrm{~cm}_{\text {year }}^{-1}$, which is limited to the near shore when compared with shallow, wide margins (e.g., the western coasts of North and South America). Abyssal depth rates are functionally zero at the time scale examined $\left(\sim 10^{-4} \mathrm{~cm}_{\text {year }}{ }^{-1}\right)$ and increase one order of magnitude near the Mid-Atlantic Ridge and at the Galapagos Triple Junction.
\end{abstract}

\section{Introduction}

The properties and distribution of seafloor sediment are controlled primarily by coastal processes that are dynamic, changing in response to both anthropogenic and natural stimuli. These properties, which influence a large swath of the benthic environment including faunal habitat, carbon sequestration, and seafloor stability, vary with water depth and proximity to sediment sources, primarily river mouths. The inherent dynamicity of coastal regions, especially those proximal to a river outlet, makes prediction of subaqueous sediment properties complex. While several coastlines are well studied with substantial efforts underway to describe hazards, sediment

Giancarlo A. Restreppo

Giancarlo.Restreppo.ctr@nrlssc.navy.mil

National Research Council (NRC), Washington, D.C., USA

2 Naval Research Laboratory, Stennis Space Center, Hancock County, MS, USA behavior, and characteristics (e.g., the Gulf Coast of the USA and the Norwegian Coast), regional studies are, by definition, geographically narrow in scope. Researchers must also implement a suite of physical tests to analyze sediment characteristics and behavior, including coring, radioisotope-based sedimentation rate calculations, grain size analysis, loss-on-ignition tests, and density analysis (e.g., Nittrouer and Sternberg 1981; Richardson et al. 2002; Keller et al. 2017; Restreppo et al. 2019). These tests require in situ sample collection, intensive subsampling, and prolonged laboratory analysis to assemble a usable data set. Spreading across tens or hundreds of cores, this work could require months to years of labor, as well as special permitting to acquire samples in sensitive areas. Therefore, a less regionally focused, more expedient method is needed for global scale sediment characterization.

By collecting coastal and oceanic sediment accumulation rates from 89 peer reviewed sources spanning the past $\sim 55$ years and pairing the data with the US Naval Research Laboratory's Global Predictive Seabed Model (GPSM), a 5arc-minute global map of vertical sedimentation rates is generated, spanning from the coastal zone to the abyssal plain 
across all oceans. Of special interest are areas in which sedimentation patterns have been understudied or where complete gaps in data exist. Vertical accumulation, when predicted at the global scale, provides a window into where sediment of all types is aggrading onto the seafloor. A precise model of vertical sediment accumulation enables researchers to link ongoing research, whether pertaining to geology, biology, engineering, etc., to sediment input into a given region.

\section{Predictive machine learning in the geosciences}

Predictive machine learning has been used to estimate unknown quantities using a set of known quantities from "previously solved cases," for quite some time (Friedman 2006). In the geosciences, these "previously solved cases" include quantifiable real-world observations, such as rates of sedimentation, grain size and content, and isotopic ratios. The application of predictive machine learning to the geosciences is a somewhat recent trend, focusing on topics such as hazard prediction, mineral prospecting, seafloor sediment porosity, behavioral characterization of rock masses, and remote sensing (Goetz et al. 2015; Martin et al. 2015; Rodiguez-Galiano et al. 2015; Lary et al. 2016). Efforts are already underway to predict deltaic changes in response to anthropogenic impacts (damming, water withdrawal, etc.) that decrease river discharge (Nienhuis et al. 2018). Additionally, research has been done to predict the influence of waves on sediment dispersal along coastline adjacent to a river outlet (Nienhuis et al. 2015). These studies, however, are focused principally on channel morphology and near river outlet sediment transport; studies on predictive benthic sediment characterization are limited. Modeling of seabed parameters has been attempted by Huang et al. (2011) and Li et al. (2012). Both studies endeavor to quantify the composition of benthic sediment in Australia, providing valid insight into regional sedimentary behavior and related problems. However, there exists no synthesized map at the global scale.

Studies that pair real world observations with machine learning techniques ( $k$-nearest neighbor and random forest) have been used to successfully predict total organic carbon on the seafloor, as well as seafloor porosity in areas with gaps in data, on a global scale (Martin et al. 2015; Lee et al. 2019). In both cases, resolution of $5 \times 5$ arc-minutes was achieved.

\section{Methods}

Vertical sediment accumulation rates from peer-reviewed literature from the year 1965 to the present were gathered for use in GPSM $(n=1031$; Table 1). These rates span coastal environments from the near shore and river-mouth proximal subaqueous deltas to the Mid-Atlantic Ridge and abyssal plain of the Pacific (Fig. 1). It should be noted these rates do not differentiate between terrigenous and biogenic sedimentation. Carbon rich, biologically derived sediment is only a small percentage of total sediment settling on the ocean floor, $160 \mathrm{Mt}$ year $^{-1}$ (Hedges and Keil 1995; Smith et al. 2015) compared with $\sim 13,500-19,100 \mathrm{Mt} \mathrm{year}^{-1}$ of fluvial sediment flux to the oceans calculated by Milliman and Meade (1983) and Milliman and Farnsworth (2011). As such, we treat sedimentation as being generally terrigenous in origin. Rates were subsequently converted to $\mathrm{cm}_{\text {year }}{ }^{-1}$ and were also transformed logarithmically to emphasize deep sea sedimentation, as this is not apparent outside of logarithmic space.

The k-nearest neighbor (k-NN) algorithm used in this study has been detailed in great technical depth in Lee et al. (2019). To briefly summarize, k-NN uses parametrically, not geospatially, nearest observed data points to calculate probable values in an area with no data. The parametric distance is calculated using predictor grids which are known or estimated properties about the water column and seafloor (i.e., water depth, distance from a river mouth, etc.) that are known globally. Predictor grids are generated from previously published research and open databases, for instance the $1 / 12^{\circ}$ global HYCOM+NCODA Ocean Reanalysis (https://hycom.org/ publications/acknowledgements/ocean-reanalysis-data) and NASA's MODIS Aqua mission (https://modis.gsfc.nasa.gov).

To select the most relevant predictors, tenfold validation is used. Tenfold validation withholds a random $10 \%$ of all observations, with the remaining $90 \%$ used to predict. This is repeated until all points have been withheld and used in prediction. During feature selection, the prediction evaluates each predictor grid individually and then cross validates to define the predictive skill of each individual grid. This is then compared with uniform random noise grids. Only the best predictors are used to define the final prediction and error; grids with errors higher than random noise grids are discarded.

The k-NN method is simpler than other available predictive methods (random forest, for example), as the only hyperparameter to manipulate within the algorithm is the number of nearest neighbors used in the prediction of each point (k). Generally, with fewer neighbors selected, individual data points begin to overinfluence the predictions; if the $k$ value is too high, oversmoothing occurs, wherein predictions begin to reflect the mean of all observed data (Zhang 2016). As follows, several predictions must be run to establish a reasonable $k$ value that minimizes standard deviation and error while maximizing the validation $R^{2}$ value. For this prediction, five nearest neighbors $(k=5)$ were used.

\section{Results}

The highest sedimentation rates $\left(\sim 3-8 \mathrm{~cm}\right.$ year $\left.{ }^{-1}\right)$ occur proximal to river outlets that drain large basins with high 
Table 1 Coastal and oceanic regions with vertical sedimentation rate observations, with sources

\begin{tabular}{ll}
\hline Region & Sources \\
\hline Arctic & Baskaran and Naidu 1995; Hulse and Bentley 2012; Ku and Broecker 1965; Macko and Aksu 1986; \\
& Szczucinski et al. (2009b); Zaborska et al. 2008. \\
Antarctic & Boldt et al. 2013; Isla et al. 2002; Masqué et al. 2002. \\
Asia (India to Japan) & Goodbred and Kuehl 1998; Hong et al. 1997; Hsu et al. 2006; Kato et al. 2003; Kuehl et al. 1993; Kumar et al. \\
& 2016; Li et al. 2006; McKee et al. 1983; Pandarinath et al. 2004; Somayajulu et al. 1999; Srisuksawad et al. \\
& 1997; Szczucinski et al. (2009a); van den Bergh et al. 2007; Zhou et al. 2016. \\
Atlantic (includes eastern North & Benoit et al. 1979; Brush et al. 1982; Buffoni et al. 1992; Canfield 1989; de Haas and van Weering 1997; Ingall \\
and South America; west Africa; & and Cappellen 1990; Kershaw 1985; Krishnaswami et al. 1984; Krom and Bennett 1985; Kuehl et al. 1986; \\
Europe) & Mattila et al. 2006; Mouret et al. 2009; Müller and Suess 1979; Nozaki et al. 1977; Palinkas and Koch 2012; \\
& Patchineelam and Smoak 1999; Schmidt et al. 2009; Van Weering et al. 1987; Wilken et al. 1986. \\
Gulf of Mexico & Allison et al. 2007; Allison et al. 2000; Canfield 1989; Corbett et al. 2006; Filipek and Owen 1980; Ingall and \\
& Cappellen 1990; Keller et al. 2017; Yeager et al. 2004. \\
Mediterranean and Adriatic Sea & Frignani et al. 2005; Palinkas and Nittrouer 2007; Sanchez-Cabeza et al. 1999; Zuo et al. 1997. \\
Pacific Islands and New Zealand & Alexander et al. 2010; Kniskern et al. 2010; Maria et al. 2009; Schmitz et al. 1986. \\
Pacific (includes western North and & Alexander and Lee 2009; Alexander and Venherm 2003; Berger and Killingley 1982; Botwe et al. 2017; \\
South America) & Cochran and Krishnaswami 1980; Hartmann et al. 1976; Ingall and Cappellen 1990; Koide et al. 1972; Lao \\
& et al. 1992; McMurtry 1981; Mitchell 1998; Müller and Suess 1979; Nittrouer et al. 1984; Stevenson and
\end{tabular}

mountainous areas that are paired with wide, shallow continental shelves, e.g., the Amazon Delta, the Huang He Delta, and the Mississippi River Delta (Fig. 2; DOI: https://doi.org/ 10.26022/IEDA/329769). The exception to this pattern is Southeast Asia and nearby islands, collectively referred to herein as Oceania, which displays the highest intensity of sedimentation over the largest area without the large drainage basins mentioned previously. Generally, shelf zones around all continents and islands display vertical sedimentation between approximately 0.1 and $1 \mathrm{~cm}$ year ${ }^{-1}$ (Fig. 2).

Rates in the deep ocean steadily decline by orders of magnitude towards deeper basins and away from subaerial land masses. The Pacific and Indian oceans contain the lowest

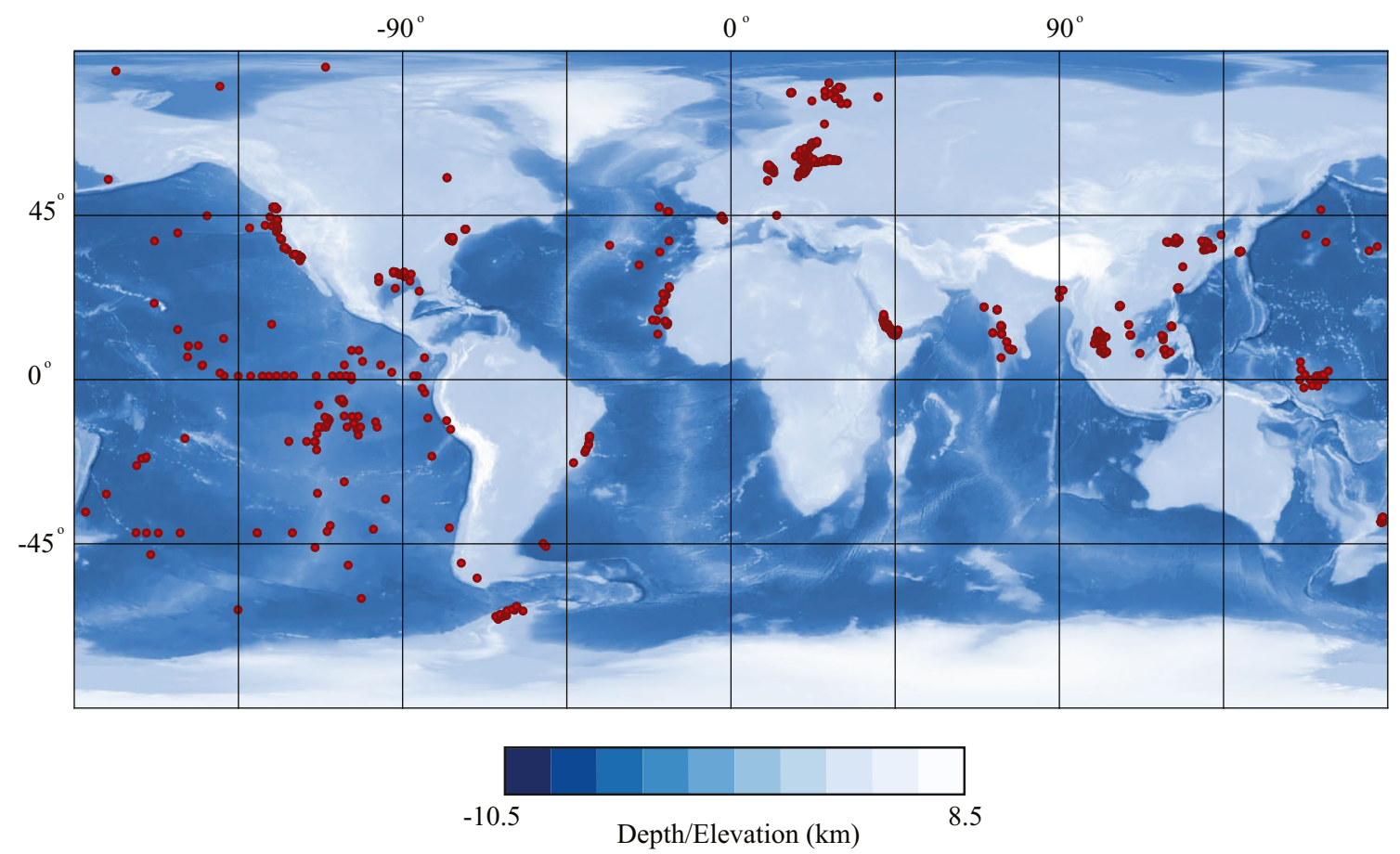

Fig. 1 Global elevation and bathymetry map with observations in red. Bathymetry taken from the GEBCO One Minute Grid (2008; https://www.gebco. net/data_and_products/historical_data_sets) 


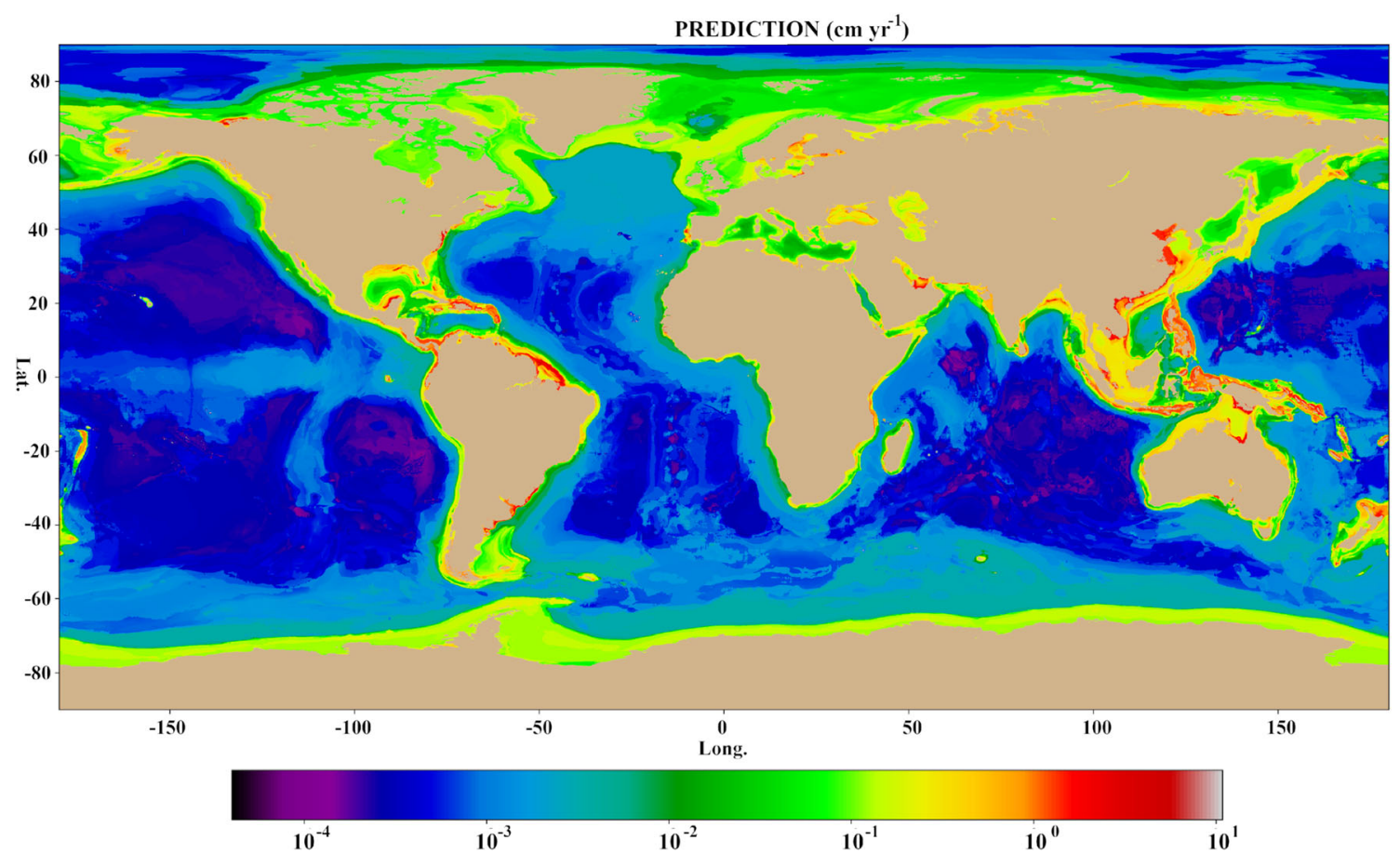

Fig. 2 Prediction of vertical sedimentation rate across all coasts and oceans. Note high rates near river outlets and shallow coasts

values, functionally zero at the yearly time scale $(\sim$ $\left.10^{-5} \mathrm{~cm} \mathrm{year}^{-1}\right)$. Rates increase slightly along the MidAtlantic Ridge and at the conjunction of the Cocos, Nazca, and Pacific tectonic plates, but remain functionally zero $(\sim$ $10^{-4} \mathrm{~cm}$ year $\left.^{-1}\right)$. The authors theorize the increase is a result of both localized sedimentation resulting from tectonic processes and associated elevated bathymetry, but may also be artifacts from the prediction process.

Coefficient of determination for the validation portion of the model is high $\left(R^{2}=0.89\right.$; Fig. 3$)$. Standard deviation of the prediction is lowest in the deep oceans and along most coastlines; deviation increases along portions of the islands of Southeast Asia, a section of the northernmost Atlantic Ocean, and across the Arctic Ocean (Fig. 4). The highest correlated predictor grids include river mouth total suspended solids (TSS), dissolved organic carbon, wave direction, mean decadal sea salinity, and megafauna biomass, of which river mouth TSS was ranked highest (Table 2).

\section{Discussion}

The predictive map of Fig. 2 is very much in line with the work of Milliman and Farnsworth (2011), which quantifies fluvial sediment discharge into the oceans from all regions, and Milliman and Syvitski (1992), which illustrates the relationship between drainage basin area, maximum elevation, and sediment flux from rivers to the oceans. Milliman and Farnsworth (2011) identify the "Austral-Asian Rivers" region, i.e., Northern Australia, the islands of Southeast Asia, and
Southeast Asia proper, which we refer to as Oceania, as discharging the most fluvial sediment into the oceans $\left(12,500 \mathrm{Mt}^{-} \mathrm{year}^{-1}\right)$, followed distantly by the Amazon region (1600 Mt year ${ }^{-1}$ ). Milliman and Syvitski (1992) also acknowledge the Oceania region yields the highest sediment loads, followed by the fluvial systems draining the Himalayas. In our prediction, the Oceania region is predicted to generate substantial vertical sedimentation over the largest area. The Amazon, Mississippi, and Ganges-Brahmaputra Deltas, among others, generate a similar magnitude of vertical sedimentation; however, the area of influence is limited compared with Oceania. Our prediction also highlights the Caribbean and the Northeastern USA, as locations of high vertical sedimentation. It should be noted that the Caribbean and Northeastern USA are not identified as contributing significant fluvial sediment to the oceans, according to Milliman and Farnsworth (2011); yet there is evidence of increased fluvial sediment discharge as a result of the twentieth century deforestation and urban development of the Caribbean islands (Alonso-Hernandez et al. 2006). Additionally, there are data indicating significant input of terrigenous sediment into the Caribbean originating from the Amazon and Orinoco Rivers of Brazil, especially during periods of high sea level (Bowles and Fleischer 1985). Thus, this carbonate rich area may be aggrading vertically with input from sediment carried from some distance away. As for the Northeastern USA, several rivers, including the Potomac and Hudson, discharge sediment originating from the northeastern Appalachian Mountains (Thompson 1939).

In Milliman and Farnsworth (2011), the third highest sediment discharging region is the west coast of North America. 
Table 2 The ten highest ranked feature grids and sources

\begin{tabular}{lll}
\hline Rank & Grid name & Source \\
\hline 1 & GL_RIVERMOUTH_CO2_TGCYR-1_ORNL.r500km.men. & Ludwig et al. (2011) \\
2 & GL_RIVERMOUTH_TSS_TGYR-1_ORNL.r500km.men. & Ludwig et al. (2011) \\
3 & SS_PIC_LOG_MOL_M3-1_MODIS_Aqua_MISSION_ & MODIS Aqua \\
4 & GL_RIVERMOUTH_TSS_TGYR-1_ORNL.r1000km.aad. & Ludwig et al. (2011) \\
5 & GL_RIVERMOUTH_DOC_TGCYR-1_ORNL.r1000km.aad. & Ludwig et al. (2011) \\
6 & GL_TOT_SED_THICK_M_CRUST1_NOAA.r1000km.aad. & Whittaker et al. \\
7 & SS_BIOMASS_MACROFAUNA_LOG10_MGCM2_ & (2013) \\
8 & SF_SEA_SALINITY_PSU_DECADAL_MEAN_woa13v2x.r250km.men. & Wei et al. (2010) \\
9 & SS_BIOMASS_MEGAFAUNA_LOG10_MGCM2_ & Woyer et al. (2013) \\
10 & SS_WAVI2010x.r50km.men. & Wei et al. (2010) \\
& WAVEWATCH3X.r1000km.aad. & HYCOM+NCDOA \\
\hline
\end{tabular}

All files suffixed 5 m.ggg; $S S$ sea surface, $S F$ sea floor, $G L$ ground level
In our prediction, this area does not appear to generate significant vertical sedimentation when compared with areas with wide, shallow margins, described previously. This may be attributed to the relatively steep bathymetric gradient of western North America, as a steep continental shelf may negate vertical sedimentation potential from a high TSS fluvial source, such as the Columbia River. First, it appears that in order for sediment to considerably accumulate vertically, depth and the gradient towards deeper bathymetry must be relatively shallow. Second, the high amount of fresh sediment

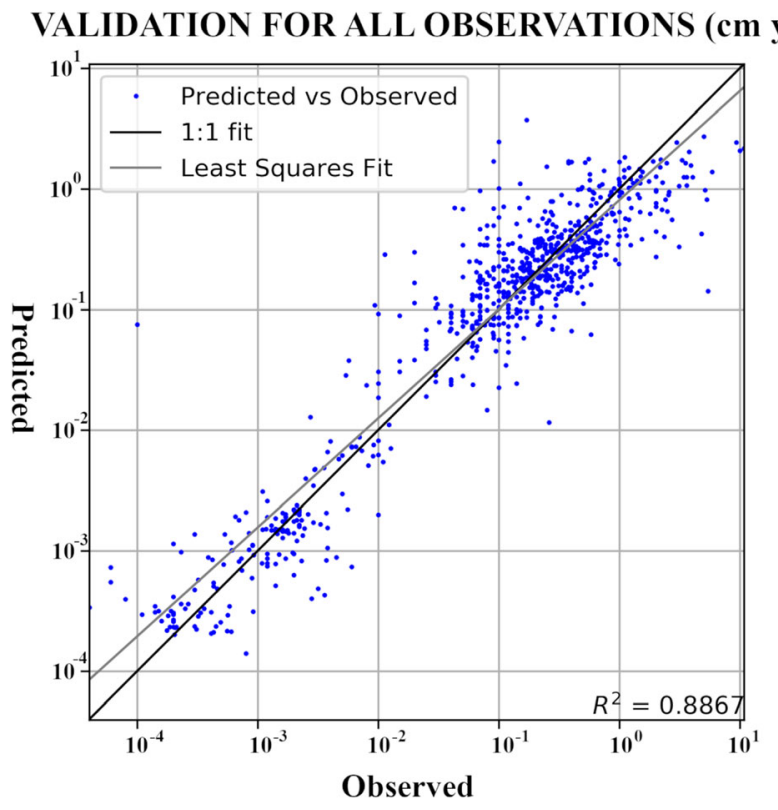

Fig. 3 Validation for the GPSM prediction settling onto these margins leaves these regions susceptible to subaqueous landslides, which may retard overall upslope accumulation; the topic of slope stability is further addressed in the next section. Finally, Milliman and Syvitski (1992) remark that the steep gradient and proximity to sediment source of these small mountainous rivers equates to larger bedload, which is not usually included in sediment discharge values.

Coastal zones that experience high sedimentation are more susceptible to develop slope stability issues, as the weight of the newly added sediment increases shear stress which can lead to slope failure and trigger powerful downslope flows in already unstable area even with a very low gradient slope (Coleman and Garrison 1977; Clare et al. 2016; Maloney et al. 2018, 2020). Additionally, newly deposited sediment lacks the consolidated cohesive strength of older sediment, compounding the problem of an already unstable seafloor (Obelcz et al. 2017). This may account for the lack of predicted sedimentation on the west coast of North and South America, and the steep gradient along the continental shelf allows for the formation of turbidity currents which quickly move sediment from the shelf edge to abyssal depths. We have not developed any predictors related to turbidity flows, so the GPSM model cannot account for this process, which resuspends and transports sediment to deeper waters. With regard to wider, shallower coastal shelfs, e.g., the Gulf of Mexico or the Eastern USA, the concern is focused on areas where dredging occurs, leaving behind steep walls of sediment with the potential for collapse, for instance in the Gulf of Mexico (Robichaux et al. 2020). Identification of these high sedimentation areas is vital in that important underwater infrastructure can be protected against destructive flows only if the threat is recognized. 


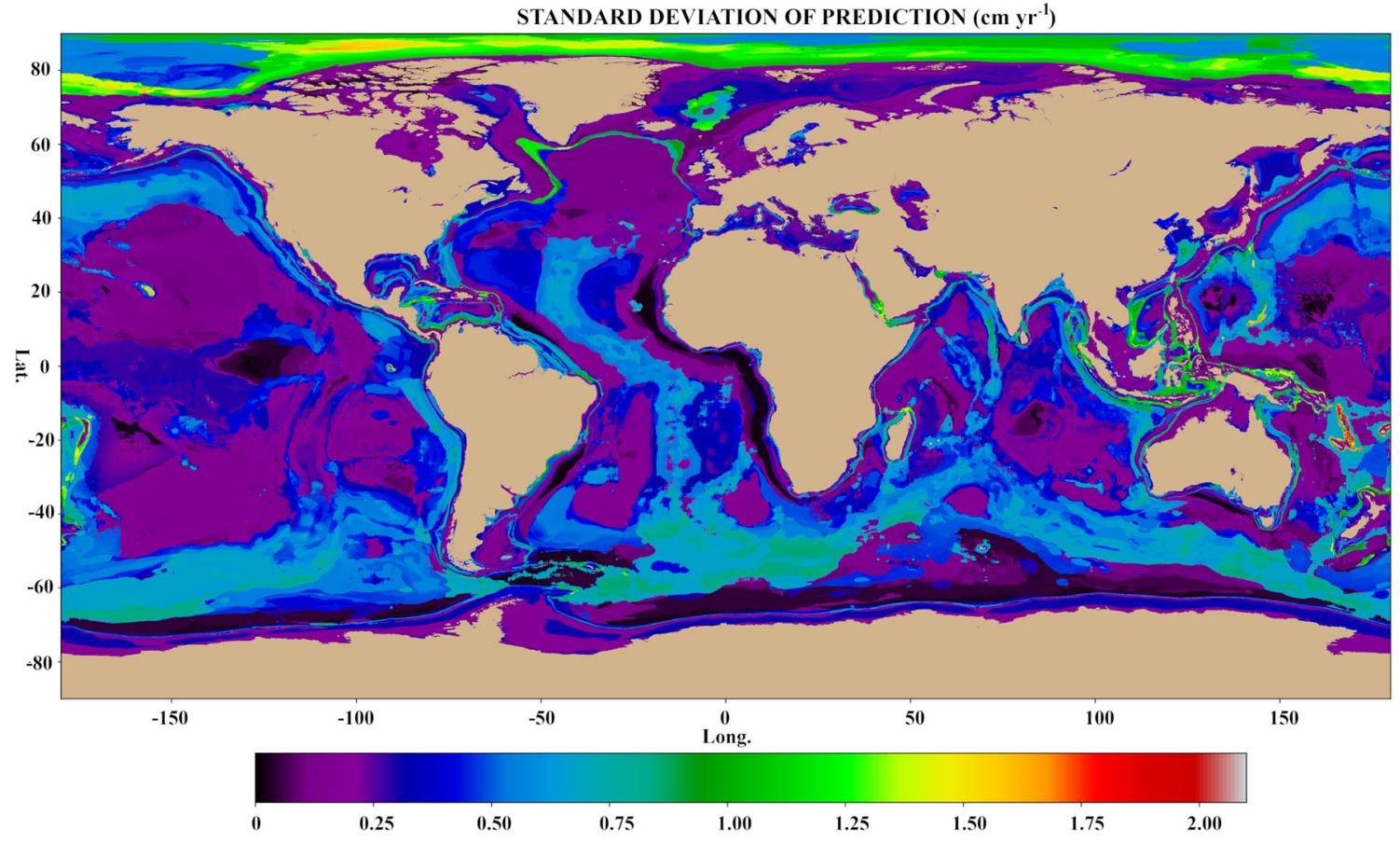

Fig. 4 Standard deviation of the prediction. Note increasing uncertainty in the Arctic region

While the majority of our prediction is substantiated by real world data and documented patterns of fluvial sediment export and migration, some elevated vertical sedimentation rates are predicted in areas with no documented significant sediment input. For example, southcentral Australia is not considered to be a significant source of sediment to the oceans (Milliman and Farnsworth 2011). Yet, St. Vincent Gulf, Spencer Gulf, and Venus Bay are all highlighted as areas of significant vertical accumulation. Unfortunately, without field work and isotope geochronology to confirm the sedimentation rates in these areas, it remains unknown if the model is correct or if GPSM is simply projecting high sedimentation values based on commonalities with other high sediment yield bays in other parts of the world. Nonetheless, it is partially the purpose of GPSM to highlight areas of interest that have had little prior study. Finally, the amount of sediment delivered to coastal zones via rivers is generally agreed to be declining due to natural and anthropogenic factors (Fan et al. 2006; Bentley et al. 2016; Bergillos et al. 2016; Maloney et al. 2018). As new, more recent sedimentation data is generated, a data driven prediction such as ours will change.

\section{Conclusion}

Presented herein is the first map of global sedimentation rates that provides a well-founded view of global, benthic sedimentation patterns with quantitative uncertainties. However, this is not a final prediction; the model is ever-evolving as new data on sedimentation rates is generated or discovered and added to the dataset. The principle results from this prediction are:

1. East Asia and Oceania are associated with the highest quantity of vertical sedimentation over the largest region. These results are in line with the fluvial TSS flux to the oceans in Milliman and Farnsworth (2011) and Milliman and Syvitski (1992).

2. The deep oceans aggrade vertically at a rate that is functionally zero at the yearly time scale, increasing one order of magnitude at the Mid-Atlantic Ridge and at the conjunction of the Pacific, Cocos, and Nazca tectonic plates.

3. The GPSM prediction confirms that the extent of vertical sedimentation appears dependent on drainage basin area, maximum elevation within the basin, and secondarily on bathymetric gradient and depth (Milliman and Syvitski 1992).

4. Identification of areas with substantial vertical sedimentation allows for the recognition of unstable, slope failure prone regions, as the two are linked. This is of special importance in areas with sensitive infrastructure on or buried in the sea floor such as offshore oil platforms and pipelines.

These results are only the first steps towards machine learning-based predictions of global sediment dynamics and characteristics. The methods used herein are currently being applied to several aspects of benthic sediment characterization in the oceans, including grain size, composition, and mass accumulation, where there exist available real-world observations for use in GPSM. 
Acknowledgments The authors would like to extend gratitude to Dr. Clark Alexander and Dr. Samuel Bentley for providing data sets for use in this manuscript, as well as Dr. Jeff Obelcz and Taylor Lee of the Naval Research Laboratory for input during the modeling phase of the project.

Funding information Giancarlo A. Restreppo is a postdoctoral associate funded by the National Academies of Sciences, Engineering, and Medicine's NRC Research Associateship.

\section{Compliance with ethical standards}

Conflict of interest The authors declare that they have no conflict of interest.

Open Access This article is licensed under a Creative Commons Attribution 4.0 International License, which permits use, sharing, adaptation, distribution and reproduction in any medium or format, as long as you give appropriate credit to the original author(s) and the source, provide a link to the Creative Commons licence, and indicate if changes were made. The images or other third party material in this article are included in the article's Creative Commons licence, unless indicated otherwise in a credit line to the material. If material is not included in the article's Creative Commons licence and your intended use is not permitted by statutory regulation or exceeds the permitted use, you will need to obtain permission directly from the copyright holder. To view a copy of this licence, visit http://creativecommons.org/licenses/by/4.0/.

\section{References}

Alexander CR, Lee HJ (2009) Sediment accumulation on the Southern California continental margin during the twentieth century. In Lee HJ and Normark WR (eds) Earth Science in the Urban Ocean: The Southern California Continental Borderland: Geological Society of America Special Paper 454, p. 69-87. doi: https://doi.org/10.1130/ 2009.2454(2.4)

Alexander CR, Venherm C (2003) Modern sedimentary processes in the Santa Monica, California continental margin: sediment accumulation, mixing and budget. Mar Environ Res 56:177-204

Alexander CR, Walsh JP, Orpin AR (2010) Modern sediment dispersal and accumulation on the outer poverty continental margin. Mar Geol 270:213-226

Allison MA, Kineke GC, Gordon ES, Goñi MA (2000) Development and reworking of a seasonal flood deposit on the inner continental shelf off the Atchafalaya River. Cont Shelf Res 20:2267-2294

Allison MA, Bianchi TS, McKee BA, Sampere TP (2007) Carbon burial on the river-dominated continental shelves: impact of historical changes in sediment loading adjacent to the Mississippi River. Geophys Res Lett 34:L01606. https://doi.org/10.1029/ 2006GL028362

Alonso-Hernandez CM, Diaz-Asencio M, Munoz-Caravaca A, Delfanti R, Papucci C, Ferretti O, Crovato C (2006) Recent changes in sedimentation regime in Cienfuegos Bay, Cuba, as inferred from ${ }^{210} \mathrm{~Pb}$ and ${ }^{137} \mathrm{Cs}$ vertical profiles. Cont Shelf Res 26:153-167

Baskaran M, Naidu AS (1995) ${ }^{210} \mathrm{~Pb}$-derived chronology and the fluxes of ${ }^{210} \mathrm{~Pb}$ and ${ }^{137} \mathrm{Cs}$ isotopes into continental shelf sediments, East Chukchi Sea, Alaskan Arctic. Geochim Cosmochim Acta 59(21): $4435-4448$

Benoit GJ, Turekian KK, Benninger LK (1979) Radiocarbon dating of a core from Long Island sound. Estuar Coast Mar Sci 9:171-180

Bentley SJ, Blum MD, Maloney J et al (2016) The Mississippi River source-to-sink system: perspectives on tectonic, climatic, and anthropogenic influences, Miocene to Anthropocene. Earth Sci Rev 153:139-174

Berger WH, Killingley JS (1982) Box cores from the equatorial Pacific: ${ }^{14} \mathrm{C}$ sedimentation rates and benthic mixing. Mar Geol 45:93-125

Bergillos RJ, López-Ruiz A, Ortega-Sánchez M, Masselink G, Losada MA (2016) Implications of delta retreat on wave propagation and longshore sediment transport - Guadalfeo case study (southern Spain). Mar Geol 382:1-16

Boldt KV, Nittrouer CA, Hallet B, Koppes MN, Forrest BK, Wellner JS, Anderson JB (2013) Modern rates of glacial sediment accumulation along a $15^{\circ} \mathrm{S}-\mathrm{N}$ transect in fjords from the Antarctic Peninsula to southern Chile. J Geophys Res Earth Surf 118:2072-2088. https:// doi.org/10.1002/jgrf.20145

Botwe BO, Abril JM, Schirone A et al (2017) Settling fluxes and sediment accumulation rates by the combined use of sediment traps and sediment cores in Tema Harbour (Ghana). Sci Total Environ 609. https://doi.org/10.1016/j.scitotenv.2017.07.139

Bowles FA, Fleischer P (1985) Orinoco and Amazon River sediment input to the eastern Caribbean Basin. Mar Geol 68:53-72

Boyer TP, Antonov JI, Baranova OK et al (2013) World Ocean Database 2013. In Levitus S and Mishonov A (Eds) NOAA Atlas NESDIS 72, Technical Ed. Silver Spring, MD. https://doi.org/10.7289/ V5NZ85MT

Brush GS, Martin EA, DeFries RS, Rice CA (1982) Comparisons of ${ }^{210} \mathrm{~Pb}$ and pollen methods for determining rates of estuarine sediment accumulation. Quat Res 18:196-217

Buffoni G, Delfanti R, Papucci C (1992) Accumulation rates and mixing processes in near-surface North Atlantic sediments: evidence from C-14 and Pu-239, 240 downcore profiles. Mar Geol 109:159-170

Canfield DE (1989) Reactive iron in marine sediments. Geochim Cosmochim Acta 53:619-632

Clare MA, Hughes Clarke JE, Talling PJ, Cartigny MJB, Pratomo DG (2016) Preconditioning and triggering of offshore slope failures and turbidity currents revealed by most detailed monitoring yet at a fjord-head delta. Earth Planet Sci Lett 450:208-220

Cochran JK, Krishnaswami S (1980) Radium, thorium, uranium, and ${ }^{210} \mathrm{~Pb}$ in deep-sea sediments and sediment pore waters from the north equatorial Pacific. Am J Sci 280:849-889

Coleman JM, Garrison LE (1977) Geological aspects of marine slope stability, northwestern Gulf of Mexico. Mar Georesour Geotechnol 2(1-4):9-44

Corbett DR, McKee B, Allison M (2006) Nature of decadal-scale sediment accumulation on the western shelf of the Mississippi River delta. Cont Shelf Res 26:2125-2140

de Haas H, van Weering TCE (1997) Recent sediment accumulation, organic carbon burial and transport in the northeastern North Sea. Mar Geol 136:173-187

Fan H, Huang H, Zeng T (2006) Impacts of anthropogenic activity on the recent evolution of the Huanghe (yellow) River Delta. J Coast Res 224:919-929

Filipek LH, Owen RM (1980) Early diagenesis of organic carbon and sulfur in outer shelf sediments from the Gulf of Mexico. Am J Sci 280:1097-1112

Friedman JH (2006) Recent advances in predictive (machine) learning. J Classif 23:175-197

Frignani M, Langone L, Ravaioli M, Sorgente D, Alvisi F, Albertazzi S (2005) Fine-sediment mass balance in the western Adriatic continental shelf over a century time scale. Mar Geol 222-223:113-133

Goetz JN, Brenning A, Petschko H, Leopold H (2015) Evaluating machine learning and statistical prediction techniques for landslide susceptibility modeling. Comput Geosci 81:1-11

Goodbred SL, Kuehl SA (1998) Floodplain processes in the Bengal Basin and the storage of Ganges-Brahmaputra river sediment: an accretion study using ${ }^{137} \mathrm{Cs}$ and ${ }^{210} \mathrm{~Pb}$ geochronology. Sediment Geol 121: 239-258 
Hartmann M, Müller PJ, Suess E, van der Weijden CH (1976) Chemistry of Late Quaternary sediments and their interstitial waters from the NW African continental margin. 'Meteor' Forsch erg C 24:1-67

Hedges JI, Keil RG (1995) Sedimentary organic matter preservation: an assessment and speculative synthesis. Mar Chem 49:81-115

Hong GH, Kim SH, Chung CS et al (1997) ${ }^{210} \mathrm{~Pb}$-derived sediment accumulation rates in the southwestern East Sea (Sea of Japan). GeoMar Lett 14:126-132

Hsu SC, Kao SJ, Jeng WL (2006) Quantitative links between fluvial sediment discharge, trapped terrigenous flux and sediment accumulation, and implications for temporal and spatial distributions of sediment fluxes. Deep-Sea Res I 53:241-252

Huang Z, Nichol SL, Siwabessy JPW et al (2011) Predictive modelling of seabed sediment parameters using multibeam acoustic data: a case study on the Carnarvon Shelf, Western Australia. Int J Geogr Inf Sci 26(2):283-307

Hulse P, Bentley SJ (2012) A ${ }^{210} \mathrm{~Pb}$ budget and granulometric record of sediment fluxes in a subarctic deltaic system: The Great Whale River, Canada. Estuar Coast Shelf Sci 109:41-52

Ingall ED, Cappellen PV (1990) Relation between sedimentation rate and burial of organic phosphorus and organic carbon in marine sediments. Geochim Cosmochim Acta 54:373-386

Isla E, Masqué P, Palanques A, Sanchez-Cabeza JA, Bruach JM, Guillén J, Puig P (2002) Sediment accumulation rates and carbon burial in the bottom sediment in a high-productivity area: Gerlache Strait (Antarctica). Deep-Sea Res II 49:3275-3287

Kato Y, Kitazato H, Shimanaga M, Nakatsuka T, Shirayama Y, Masuzawa T (2003) ${ }^{210} \mathrm{~Pb}$ and ${ }^{137} \mathrm{Cs}$ in sediments from Sagami Bay, Japan: sedimentation rates and inventories. Prog Oceanogr 57:77-95

Keller G, Bentley SJ, Georgiou IY, Maloney J, Miner MD, Xu K (2017) River-plume sedimentation and ${ }^{210} \mathrm{~Pb} /{ }^{7} \mathrm{Be}$ seabed delivery on the Mississippi River delta front. Geo-Mar Lett 37:259-272

Kershaw PJ $(1985){ }^{14} \mathrm{C}$ and ${ }^{210} \mathrm{~Pb}$ in NE Atlantic sediments: evidence of biological reworking in the context of radioactive waste disposal. $\mathrm{J}$ Environ Radioact 2:115-134

Kniskern TA, Kuehl SA, Harris CK, Carter L (2010) Sediment accumulation patterns and fine-scale strata formation on the Waiapu River shelf, New Zealand. Mar Geol 270:188-201

Koide M, Soutar A, Goldberg ED (1972) Marine geochronology with ${ }^{210} \mathrm{~Pb}$. Earth Planet Sci Lett 14:442-446

Krishnaswami S, Monaghan MC, Westrich JT, Bennett JT, Turekian KK (1984) Chronologies of sedimentary processes in sediments of the FOAM site, Long Island sound, Connecticut. Am J Sci 284:706733

Krom MD, Bennett JT (1985) Sources, deposition rates and decomposition of organic carbon in recent sediment of Sachem Head Harbor, Long Island Sound. Estuar Coast Shelf Sci 21:325-336

Ku TL, Broecker WS (1965) Rates of sedimentation in the Arctic Ocean. Prog Oceanogr 4:95-104

Kuehl SA, DeMaster DJ, Nittrouer CA (1986) Nature of sediment accumulation on the Amazon continental shelf. Cont Shelf Res 6(1/2): 209-225

Kuehl SA, Fuglseth TJ, Thunell RC (1993) Sediment mixing and accumulation rates in the Sulu and South China Seas: implications for organic carbon preservation in deep-sea environments. Mar Geol 111:15-35

Kumar A, Rout S, Singhal RK, Ravi PM, Tripathi RM (2016) Sediment accumulation and bio-diffusion mixing rates derived from excess ${ }^{210} \mathrm{~Pb}$ and ${ }^{137} \mathrm{Cs}$ profiles in sediment cores of Mumbai Harbor Bay. J Coast Conserv 20:289-297

Lao Y, Anderson RF, Broecker WS et al (1992) Transport and burial rates of ${ }^{10} \mathrm{Be}$ and ${ }^{231} \mathrm{~Pa}$ in the Pacific Ocean during the Holocene period. Earth Planet Sci Lett 113:173-189

Lary DJ, Alavi AH, Gandomi AH, Walker AL (2016) Machine learning in geosciences and remote sensing. Geosci Front 7(1):3-10
Lee TR, Wood WT, Phrampus BJ (2019) A machine learning (kNN) approach to predicting global seafloor total organic carbon. Glob Biogeochem Cycles 33:37-46. https://doi.org/10.1029/ 2018GB005992

Li F, Li X, Song J et al (2006) Sediment flux and source in northern Yellow Sea by ${ }^{210} \mathrm{~Pb}$ technique. Chin J Oceanol Limnol 24(3): 255-263

Li J, Potter A, Huang Z, Heap AD (2012) Predicting seabed sand content across the Australian margin using machine learning and geostatistical methods. Record 2012/48. Geoscience Australia, Canberra, $130 \mathrm{pp}$

Ludwig W, Amiotte-Suchet P, Probst JL et al (2011) ISLSCP II global river fluxes of carbon and sediments to the oceans. In: Hall FG, Collatz G, Meeson B et al (eds) ISLSCP initiative II collection. Oak Ridge National Laboratory Distributed Active Archive Center, Oak Ridge. https://doi.org/10.3334/ORNLDAAC/1028

Macko SA, Aksu AE (1986) Amino acid epimerization in planktonic foraminifera suggests slow sedimentation rates for Alpha Ridge, Arctic Ocean. Nature 322:730-732

Maloney JM, Bentley SJ, Xu K, Obelcz J, Georgiou IY, Miner MD (2018) Mississippi River subaqueous delta is entering a stage of retrogradation. Mar Geol 400:12-23

Maloney JM, Bentley SJ, Xu K et al (2020) Mass wasting on the Mississippi River subaqueous delta. Earth Sci Rev 200:103001. https://doi.org/10.1016/j.earscirev.2019.103001

Maria EJS, Siringan FP, Bulos AM, Sombrito EZ (2009) Estimating sediment accumulation rates in Manila Bay, a marine pollution hot spot in the Seas of East Asia. Mar Pollut Bull 59:164-174

Martin KM, Wood WT, Becker JJ (2015) A global prediction of seafloor sediment porosity using machine learning. Geophys Res Lett 42: 10640-10646. https://doi.org/10.1002/2015GL065279

Masqué P, Isla E, Sanchez-Cabeza JA, Palanques A, Bruach JM, Puig P, Guillén J (2002) Sediment accumulation rates and carbon fluxes to bottom sediments at the Western Bransfield Strait (Antarctica). Deep-Sea Res II 49:921-933

Mattila J, Kankaanpää H, Ilus E (2006) Estimation of recent sediment accumulation rates in the Baltic Sea using artificial radionuclides ${ }^{137} \mathrm{Cs}$ and ${ }^{239,240} \mathrm{Pu}$ as time markers. Boreal Environ Res 11:95-107

McKee BA, Nittrouer CA, DeMaster DJ (1983) Concepts of sediment deposition and accumulation applied to the continental shelf near the mouth of the Yangtze River. Geology 11:631-633

McMurtry GM (1981) Sediment accumulation rate patterns on the Northwest Nazca plate. Geol Soc Am Memoir 154:211-250

Milliman JD, Farnsworth KL (2011) River discharge to the coastal ocean: a global synthesis. Cambridge University Press

Milliman JD, Meade RH (1983) World-wide delivery of river sediment to the oceans. J Geol 91:1-21

Milliman JD, Syvitski JPM (1992) Geomorphic/tectonic control of sediment discharge to the oceans: the importance of small mountainous rivers. J Geol 100:525-544

Mitchell NC (1998) Sediment accumulation rates from deep tow profiler records and DSDP leg 70 cores over the Galapagos spreading centre. In: Cramp A, Macleod CJ, Lee SV, Jones EJW (eds) Geological evolution of ocean basins: results from the ocean drilling program. Geological Society, London, Special Publications, 131, pp 199-209

Mouret A, Anschutz P, Lecroart P, Chaillou G, Hyacinthe C, Deborde J, Jorissen FJ, Deflandre B, Schmidt S, Jouanneau JM (2009) Benthic geochemistry of manganese in the Bay of Biscay, and sediment mass accumulation rate. Geo-Mar Lett 29:133-149. https://doi.org/ 10.1007/s00367-008-0130-6

Müller PJ, Suess E (1979) Productivity, sedimentation rate, and sedimentary organic matter in the oceans - I. organic carbon preservation. Deep-Sea Res 26A:1347-1362

Nienhuis JH, Ashton AD, Giosan L (2015) What makes a delta wavedominated? Geology 43(6):511-514 
Nienhuis JH, Hoitink AJF, Törnqvist TE (2018) Future change to tideinfluenced deltas. Geophys Res Lett 45:3499-3507

Nittrouer CA, Sternberg RW (1981) The formation of sedimentary strata in an allochthonous shelf environment: the Washington continental shelf. Mar Geol 42(1-4):201-232

Nittrouer CA, DeMaster DJ, McKee BA et al (1984) The effect of sediment mixing on $\mathrm{Pb}-210$ accumulation rates for the Washington continental shelf. Mar Geol 54:201-221

Nozaki Y, Cochran JK, Turekian KK (1977) Radiocarbon and ${ }^{210} \mathrm{~Pb}$ distribution in submersible-taken deep-sea cores from Project FAMOUS. Earth Planet Sci Lett 34:167-173

Obelcz J, Xu K, Georgiou IY et al (2017) Sub-decadal submarine landslides are important drivers of deltaic sediment flux: insights from the Mississippi River Delta Front. Geology 45(8):703-706

Palinkas CM, Koch EW (2012) Sediment accumulation rates and submersed aquatic vegetation (SAV) distribution in the mesohaline Chesapeake Bay, USA. Estuar Coasts 35:1416-1431

Palinkas CM, Nittrouer CA (2007) Modern sediment accumulation on the Po shelf, Adriatic Sea. Cont Shelf Res 27:489-505

Pandarinath K, Verma SP, Yadava MG (2004) Dating of sediment layers and sediment accumulation studies along the western continental margin of India: a review. Int Geol Rev 46(10):939-956. https:// doi.org/10.2747/0020-6814.46.10.939

Patchineelam SR, Smoak JM (1999) Sediment accumulation rates along the inner eastern Brazilian continental shelf. Geo-Mar Lett 19:196201

Restreppo GA, Bentley SJ, Wang J, Xu K (2019) Riverine sediment contribution to distal deltaic wetlands: Fourleague Bay, LA. Estuar Coasts 42(1):55-67

Richardson MD, Briggs KB, Bentley SJ, Walter DJ, Orsi TH (2002) The effects of biological and hydrodynamic processes on physical and acoustic properties of sediments off the Eel River, California. Mar Geol 182(1-2):121-139

Robichaux P, Xu K, Bentley SJ et al (2020) Morphological evolution of a mud-capped dredge pit on the Louisiana shelf: Nonlinear infilling and continuing consolidation. Geomorphology 354:107030. https:// doi.org/10.1016/j.geomorph.2019.107030

Rodiguez-Galiano V, Sanchez-Castillo M, Chica-Olmo M, Chica-Rivas M (2015) Machine learning predictive models for mineral prospectivity: an evaluation of neural networks, random forest, regression trees and support vector machines. Ore Geol Rev 71:804 818

Sanchez-Cabeza JA, Masqué P, Ani-Ragolta I, Merino J, Frignani M, Alvisi F, Palanques A, Puig P (1999) Sediment accumulation rates in the southern Barcelona continental margin (NW Mediterranean Sea) derived from ${ }^{210} \mathrm{~Pb}$ and ${ }^{137} \mathrm{Cs}$ chronology. Prog Oceanogr 44: 313-332

Schmidt S, Howa H, Mouret A, Lombard F, Anschutz P, Labeyrie L (2009) Particle fluxes and recent sediment accumulation on the Aquitanian margin of Bay of Biscay. Cont Shelf Res 29:1044-1052

Schmitz W, Mangini A, Stoffers P, Glasby GP, Plüger WL (1986) Sediment accumulation rates in the southwestern Pacific basin and Aitutaki passage. Mar Geol 73:181-190

Smith RW, Bianchi TS, Allison M, Savage C, Galy V (2015) High rates of organic carbon burial in fjord sediments globally. Nat Geosci 8: $450-453$

Somayajulu BLK, Bhushan R, Sarkar A et al (1999) Sediment deposition rates on the continental margins of the eastern Arabian Sea using ${ }^{210} \mathrm{~Pb},{ }^{137} \mathrm{Cs}$ and ${ }^{14} \mathrm{C}$. Sci Total Environ 237(238):429-439
Srisuksawad K, Porntepkasemsan B, Nouchpramool S et al (1997) Radionuclide activities, geochemistry, and accumulation rates of sediments in the Gulf of Thailand. Cont Shelf Res 14(8):925-965

Stevenson FJ, Cheng C-N (1972) Organic geochemistry of the Argentine Basin sediments: carbon-nitrogen relationships and quaternary correlations. Geochim Cosmochim Acta 36:653-671

Szczucinski W, Stattegger K, Scholten J (2009a) Modern sediments and sediment accumulation rates on the narrow shelf off Central Vietnam, South China Sea. Geo-Mar Lett 29:47-59

Szczucinski W, Zajaczkowski M, Scholten J (2009b) Sediment accumulation rates in subpolar fjords - impact of post-Little Ice Age glaciers retreat, Billefjorden, Svalbard. Estuar Coast Shelf Sci 85:345-356

Thompson HD (1939) Drainage evolution in the southern Appalachians. GSA Bull 50:1323-1356

Thorbjarnarson KW, Nittrouer CA, DeMaster DJ (1986) Accumulation of modern sediment in Quinault Submarine Canyon. Mar Geol 71: $107-124$

van den Bergh GD, Boer W, Schaapveld MAS, Duc DM, van Weering TCE (2007) Recent sedimentation and sediment accumulation rates of the Ba Lat prodelta (Red River, Vietnam). J Asian Earth Sci 29: $545-557$

Van Weering TCE, Berger GW, Kalf J (1987) Recent sediment accumulation in the Skagerrak, northeaster North Sea. Neth J Sea Res 21(3): 177-189

Wei C, Rowe GT, Escobar-Briones E et al (2010) Global patterns and predictions of seafloor biomass using random forests. PLOS ONE 5(12):e15323. https://doi.org/10.1371/journal.pone.0015323

Wheatcroft RA, Sommerfield CK (2005) River sediment flux and shelf sediment accumulation rates on the Pacific northwest margin. Cont Shelf Res 25:311-332

Whittaker J, Goncharov A, Williams S et al (2013) Global sediment thickness dataset updated for the Australian-Antarctic Southern Ocean. Geochem Geophys Geosyst 14(8):3297-3305

Wilken RD, Moreira I, Rebello A $(1986){ }^{210} \mathrm{~Pb}$ and ${ }^{137} \mathrm{Cs}$ fluxes in a sediment core from Guanabara Bay, Brazil. Sci Total Environ 58: 195-198

Yeager KM, Santschi PH, Rowe GT (2004) Sediment accumulation and radionuclide inventories $\left({ }^{239,240} \mathrm{Pu},{ }^{210} \mathrm{~Pb}\right.$, and $\left.{ }^{234} \mathrm{Th}\right)$ in the northern Gulf of Mexico, as influenced by organic matter and macrofaunal density. Mar Chem 91:1-14

Zaborska A, Carroll J, Papucci C, Torricelli L, Carroll ML, WalkuszMiotk J, Pempkowiak J (2008) Recent sediment accumulation rates for the Western margin of the Barents Sea. Deep-Sea Res II 55: $2352-2360$

Zhang Z (2016) Introduction to machine learning: k-nearest neighbors. Ann Translat Med 4(11):218-223. https://doi.org/10.21037/atm. 2016.03.37

Zhou L, Liu J, Saito Y, Gao M, Diao S, Qiu J, Pei S (2016) Modern sediment characteristics and accumulation rates from the delta front to prodelta of the Yellow River (Huanghe). Geo-Mar Lett 36:247258

Zuo Z, Eisma D, Gieles R, Beks J (1997) Accumulation rates and sediment deposition in the northwestern Mediterranean. Deep-Sea Res II 44(3-4):597-609

Publisher's note Springer Nature remains neutral with regard to jurisdictional claims in published maps and institutional affiliations. 